28 Mansell W, Pedley R. The ascent into mania: a review of psychological processes associated with the development of manic symptoms. Clin Psychol Rev 2008; 28: 494-520.

29 Berridge KC, Robinson TE. Parsing reward. Trends Neurosci 2003; 9: 507-13.

30 Khanna S, Vieta E, Lyons B, Grossman F, Eedekens M, Kramer M. Risperidone in the treatment of acute mania. Double-blind, placebo-controlled study. Br J Psychiatry 2005; 187: 229-34.

31 Wolf R. Evaluation of several formulae for correction of item-tota correlations in item analysis. J Educat Measur 1967; 4: 21-6.

32 Beaulieu JM, Sotnikova TD, Yao WD, Kockeritz L, Woodgett JR, Gainetdinov $\mathrm{RR}$, et al. Lithium antagonises dopamine-dependent behaviors mediated by an AKT/glycogen synthase kinase 3 signaling cascade. Proc Natl Acad Sci USA 2004; 101: 5099-104.
33 Scott J, Paykel E, Morriss R, Bentall R, Kinderman P, Johnson T, et al. Cognitive-behavioural therapy for severe and recurrent bipolar disorders. Randomised controlled trial. Br J Psychiatry 2006; 188: 313-20.

34 Colom F, Vieta E, Martinez-Aran A, Reinares M, Goikolea JM, Benabarre A, et al. A randomized trial on the efficacy of group psychoeducation in the prophylaxis of recurrences in bipolar patients whose disease is in remission. Arch Gen Psychiatry 2003; 60: 402-7.

35 Lam DH, Hayward P, Watkins ER, Wright K, Sham P. Relapse prevention in patients with bipolar disorder: Cognitive therapy outcome after 2 years. Am J Psychiatry 2005; 162: 324-9.

36 Perry A, Tarrier N, Morriss R, McCarthy E, Limb K. Randomised controlled trial of efficacy of teaching patients with bipolar disorder to identify early symptoms of relapse and obtain treatment. BMJ 1999; 318: 149-53.

\section{Poems by doctors}

\title{
Watching someone die
}

\section{Lenrie Peters}

Watching someone die

is a fraudulent experience

The deep significance is felt

the meaning escapes

like a child's first punishment.

The dying ravish your strength

whether by throttle of convulsive gasp

or tideless fading away

like ancient familiar sounds in sea shells

the moment is the same

reinforced brutality to life

a rugged cliff bloodstained

with the agonising rhythm of many heads.

A cold demise; each

successive moment a banishment.

The terror is in leaving behind

the ache is in departing.

Humming fantasies crowd their stings

to seize and record the moment

the hands curl in spasm

to hold it back; this life, this infidel.

It is too late. Everything and nothing

has happened. A huge machine

the earth, grinds to a bolt-knocking halt.

It is the changing of the tide

at the boundary hour

Life like a handful of feathers

engulfed by cliff winds

one like yourself swept

Oh so swiftly into the anchorage of history

Tears and sighs; sighs and tears

stamping the leaden feet

the solid agony of years

they all abound.

one life or a million

contrived by nature or by man

greatly obscures the issue.

Face to face with dying

you are none-the-wiser

Yet it seems a most ignoble epitaph

'He was a man and had to die; after all.'

Lenrie Peters was born in Bathurst (Banjul), The Gambia, in 1932. He studied medicine at Trinity College Cambridge and later trained as a surgeon. He currently practises in The Gambia. He has been Chairman of the West African Examinations Council. He has published one novel, The Second Round, and four volumes of poetry - Poems (Mbari Press, 1964), Satellites (Heinemann, 1967), Katchikali (Heinemann, 1971) and Selected Poetry (Heinemann, 1981). He is the Officer of the Republic of the Gambia. This poem is taken from Satellites by kind permission of the author.

Selected by Femi Oyebode. 